DOI: 10.46340/eppd.2021.8.2.20

Yurii Popko

ORCID ID: https://orcid.org/0000-0002-2253-8165

Lviv State University of Internal Affairs, Ukraine

\title{
THE CONCEPT AND SOURCES \\ OF LEGAL REGULATION OF THE STATUS \\ OF AGRICULTURAL LEGAL ENTITIES
}

\section{Юрій Попко}

Львівський державний університет внутрішніх справ, Україна

\section{ПОНЯТТЯ ТА ДЖЕРЕЛА ПРАВОВОГО РЕГУЛЮВАННЯ СТАТУСУ СІЛЬСЬКОГОСПОДАРСЬКИХ ЮРИДИЧНИХ ОСІБ}

In the current context of market reforms, the issues of the place of agricultural legal entities among economic entities, their role and purpose have been actively discussed. In this regard, as well as after the adoption of legislative reforms in the field of agricultural land circulation in Ukraine, it is important to study the concept and sources of legal regulation of the status of the agricultural legal entities.

In the legal literature there are scientific works on the problems of legal regulation of certain types and organizational and legal forms of legal entities that carry out or can carry out certain activities in the field of agricultural commodity production. At the same time, it is expedient to comprehensively study their status in the context of reforming the legislation of Ukraine and harmonizing it with the legislation of the European Union. Legal entities engaged in their main or additional business or non-commercial activities in the field of agricultural production may be referred to agricultural legal entities. Cooperatives and farms, in particular, have become examples of inconsistencies in the legal regulation of the status of certain types of agricultural legal entities.

A significant number of regulations that define the status of legal entities entitled to carry out production activities in the field of agriculture on the one hand is a positive phenomenon, because it provides maximum regulation of relevant relations. However, on the other hand it has some negative consequences. In particular, legal acts sometimes contain mutually exclusive or contradictory rules, which complicates law enforcement. Thus, taking into aacount the land reform carried out in Ukraine, there is the urgent need to unify approaches in the field of regulating the status of legal entities operating in the field of agriculture.

Keywords: legal entity, agricultural legal entities, cooperative, partnership, farm.

Постановка проблеми. У Декларації Всесвітнього саміту з продовольчої безпеки (Рим, 2009 рік) підкреслено, що фермерські господарства покликані зіграти одну з вирішальних ролей у забезпеченні населення продуктами харчування ${ }^{1}$. Вирішення такого завдання $€$ неможливим без ефективного правового регулювання загалом суспільних відносин, пов'язаних із створенням, діяльністю та припиненням юридичних осіб, що здійснюють свою діяльність у сфері сільського господарства. У юридичній науці активно обговорюють проблеми про місце таких юридичних осіб серед суб'єктів господарської діяльності, їхню роль та призначення. У зв'язку з цим, а також опісля прийняття законодавчих реформ у сфері обігу земель сільськогосподарського призначення в Україні, актуальним $\epsilon$ дослідження питань щодо поняття та джерел правового регулювання сільськогосподарських юридичних осіб.

\footnotetext{
${ }^{1}$ The Food and Agriculture Organization of the UN (2009). Декларащия Всемирного саммита по продовольственной безопасности (Рим, 16-18 ноября) <http://www.fao.org/fileadmin/templates/wsfs/Summit/Docs/Final_Declaration/ K6050_Rev10_WSFS_OEWG_ru.pdf $\geq(2020$, листопад, 10).
} 
Аналіз останніх досліджень. У правничій літературі існують наукові праці, присвячені проблемам правового регулювання окремих видів юридичних осіб, що здійснюють чи можуть провадити діяльність у галузі сільськогосподарського товарного виробництва. Поряд з тим існує доцільність комплексного дослідження їхнього статусу в умовах реформування законодавства України та гармонізації його з правом Свропейського Союзу. Серед науковців, які вивчали дану проблематику, - О.М. Вінник ${ }^{1}$, В.М. Коссак ${ }^{2}$, Н.С. Кузнєцова ${ }^{3}$, I.М. Кучеренко ${ }^{4}$, Х.В. Майкут I.В. Спасибо-Фатєєва ${ }^{6}$, В.І. Цікало ${ }^{7}$, Ю.М. Юркевич ${ }^{8}$ та багато інших.

Постановка завдання. Метою цієї статті є дослідження поняття та джерел правового регулювання сільськогосподарських юридичних осіб в Україні, а також вироблення власного підходу щодо перспектив удосконалення законодавчої регламентації відповідних відносин.

Виклад основного матеріалу. Юридичною особою вважають організацію, яка створена та зареєстрована у встановленому законом порядку. Загальні умови створення і реєстрації юридичних осіб будь-якого виду та організаційно-правової форми визначені Законом України «Про державну реєстрацію юридичних осіб, фізичних осіб-підприємців та громадських формувань». Після набрання чинності Цивільним кодексом України набув усталеної практики підхід, відповідно до якого юридичні особи створюються, як правило, із загальною правоздатністю, тобто вправі здійснювати будь-яку діяльність, яка не заборонена законом. Поряд 3 тим для окремих видів та організаційноправових форм передбачені спеціальні умови їх створення (наприклад, такі правила стосуються виробничих кооперативів, фермерських господарств, акціонерних товариств тощо).

Як вказує В.С. Щербина, понять «юридична особа» і «фізична особа» виявляється зовсім недостатньо для багатоманітного господарського життя, учасники якого виконують різні завдання в різних сферах і галузях господарювання, для чого (з урахуванням економічного характеру їх діяльності) наділяються різними за обсягом правами і обов'язками, що вирізняють їх 3-поміж інших учасників господарських відносин ${ }^{9}$. При цьому в навчальній та науковій літературі існує багато критеріїв класифікації відносин за участю юридичних осіб. Так, О.М. Вінник за галузями економіки та сферами управління виділяє господарські відносини в промисловості, в агропромисловому комплексі, в галузі транспорту, в капітальному будівництві, на ринку цінних паперів, у сфері економічної конкуренції та антимонопольного регулювання тощо ${ }^{10}$. Виходячи із цього, погоджуючись із таким підходом, вважаємо за необхідне зауважити, що станом на сьогодні ціла низка юридичних осіб здійснюють свою основну або додаткову підприємницьку чи некомерційну діяльність угалузі сільськогосподарського виробництва, а тому можуть бути поіменовані як сільськогосподарські юридичні особи. Поряд із тим до категорії цих суб'єктів не можна відносити юридичних осіб, які не займаються виробничою діяльністю у галузі сільського господарства, а посередницькою, торговельною чи іншою, наприклад провадять діяльність винятково 3 продажу сільськогосподарської продукції.

\footnotetext{
${ }^{1}$ Вінник, О. М. (1998). Господарські товариства і виробничі кооперативи: правове становище. Київ: Знання.

${ }^{2}$ Коссак, В. М. (1990). Совершенствование правового регулирования юридической ответственности кооперативных организаций. Проблемы права кооперативной собственности и юридической ответственности участников кооперативного движения в правоприменительной и правотворческой деятельности. Харьков, 49-52.

${ }^{3}$ Кузнецова, Н. С. (2012). Поняття й класифікація юридичних осіб в цивільному праві україни: теорія і практика. Сучасні проблеми приватного права: збірник наукових праць присвячених 80-ій річниці з Дня народження Ярославни Миколаївни Шевченко. Київ: Асоціація цивілістів України; Кам'янець-Подільський: Рута, 159-176. ${ }^{4}$ Кучеренко, I. М. (2004). Організаційно-правові форми юридичних осіб приватного права: дисертація на здобуття наукового ступеня доктора юридичнх наук. Київ: Інститут держави і права ім. В.М.Корецького НАН України.

${ }^{5}$ Юркевич, Ю. М. (ред.) (2019). Правові засади створення, діяльності та припинення юридичних осіб в Україні. Львів: ЛьвДУВС.

${ }^{6}$ Спасибо-Фатєєва, I. В. (2014). Вчення про корпоративні права і цивілістична доктрина. Право України, 6, 84-92. <http://dspace. nlu.edu.ua/bitstream/123456789/6144/1/Spasybo-Fatieieva_84_92.pdf> (2021, березень, 02).

${ }^{7}$ Цікало, В. І. (2008). Основи правового регулювання підприємницької діяльності. В: Ортинський, В. Л., Грищук, В. К., Мацько, М. А. (ред.) (2008). Основи держави і права Украӥни. Київ: Знання, IV, 583.

${ }^{8}$ Юркевич, Ю. М. (2016). Фермерське господарство як об’єднання фізичних осіб з метою реалізації підприємницьких інтересів у сфері здійснення професійної діяльності. Актуальні проблеми держави і права, 77, 209-214.

${ }^{9}$ Щербина, В. С. (2008). Суб’єкти господарського права. Київ: Юрінком Інтер, 18.

${ }^{10}$ Вінник, О. М. (2009). Господарське право. Київ: Правова єдність, 30.
} 
Комплексне вивчення проблем правового регулювання допомагає вирішенню основних питань, пов'язаних з впливом права на сільське господарство, і розкриває значення цього регулювання як важливого політичного, економічного і соціального фактору. Воно дозволяє проаналізувати весь процес впливу права на розвиток сільського господарства як галузі в цілому, дає можливість також показати засоби i методи, за допомогою яких держава здійснює своє втручання в сільськогосподарське виробництво, розкрити його справжню сутність i зміст $\mathrm{i}$, що найголовніше, показати всі ці явища у взаємозв'язку і взаємозалежності. Розгляд проблем правового регулювання дозволяє розкрити вплив права, його доктрин і концепцій, виявити тенденції розвитку законодавчого регулювання, його форми ${ }^{1}$.

Так, початково, після здобуття Україною незалежності, правове регулювання порядку створення і діяльності осіб у сфері сільського господарства регулювалося такими законодавчими актами як: Цивільний кодекс Української РСР (1963 рік) $)^{2}$, «Про підприємства в Україні» (1991 рік) ${ }^{3}$, «Про підприємництво» (1991 рік) ${ }^{4}$, «Про селянське (фермерське) господарство» (1991 рік) ${ }^{5}$, «Про промислово-фінансові групи в Україні» (1995 рік) ${ }^{6}$ тощо. Крім цього, варто згадати і про чинні досі Закон України «Про господарські товариства» (1991 рік) ${ }^{7}$, Закон України «Про колективне сільськогосподарське підприємство» ${ }^{8}$, Закон України «Про споживчу кооперацію» (1992 рік) тощо ${ }^{9}$

Одночасно такі організаційно-правові форми підприємств, як приватні та сімейні сприймалися першими юридичними особами, які надають можливість особі займатися підприємницькою діяльністю, а нині вони визнаються архаїчними організаційно-правовими формами юридичних осіб приватного права ${ }^{10}$.

Станом на сьогодні, говорячи про систему нормативно-правових актів, які забезпечують правове регулювання відносин створення, діяльності та припинення сільськогосподарських юридичних осіб, маємо додатково зазначити про: Цивільний кодекс України (далі - ЦК України) ${ }^{11}$, Господарський кодекс України (далі - ГК України) $)^{12}$, Закон України «Про державну реєстрацію юридичних осіб, фізичних осіб-підприємців та громадських формувань» ${ }^{13}$, Закон України «Про холдингові компанії в Україні» ${ }^{14}$, Закон України «Про кооперацію» ${ }^{15}$, Закон України

\footnotetext{
${ }^{1}$ Клюкин, Б. Д. (1972). Правовое регулирование сельского хозяйства в США: автореферат диссертации на соискание научной степени доктора юридческих наук. Москва: Академия наук СССР. Институт государства и права, 3-4.

${ }^{2}$ Цивільний кодекс Украӥнської РСР, 1963 (втратив чинність) (Верховна Рада УРСР). Офіційний сайт Верховної Ради Украӥни <https://zakon.rada.gov.ua/laws/show/1540-06\#Text> (2021, лютий, 12).

3 Закон про підприємства в Україні, 1991 (втратив чинність) (Верховна Рада України). Офіиійний сайт Верховної Ради України <https://zakon.rada.gov.ua/laws/show/887-12\#Техt> (2021, лютий, 12).

4 Закон про підприємництво, 1991 (втратив чинність, окрім ст. 4). (Верховна Рада України). Офіційний сайт Верховної Ради Украӥни <https://zakon.rada.gov.ua/laws/show/698-12\#Text> (2021, лютий, 12).

5 Закон про селянське (фермерське) господарство, 1991 (втратив чинність) (Верховна Рада України).

Офіиійний сайт Верховної Ради України <https://zakon.rada.gov.ua/laws/show/2009-12\#Техt> (2021, лютий, 12).

6 Закон про промислово-фінансові групи в Україні, 1995 (втратив чинність). (Верховна Рада України).

Офіиійний сайт Верховної Ради Украӥни <https://zakon.rada.gov.ua/laws/show/437/95-\%D0\%B2\%D1\%80\#Text> (2021, лютий, 12).

7 Закон про господарські товариства, 1991 (Верховна Рада України). Офіиійний сайт Верховної Ради Украӥни <https://zakon.rada.gov.ua/laws/show/1576-12\#Техt> (2021, лютий, 12).

8 Закон про колективне сільськогосподарське підприємство, 1992 (Верховна Рада України). Офіційний сайт

Верховної Ради України <https://zakon.rada.gov.ua/laws/show/2114-12\#Tехt> (2021, лютий, 12).

9 Закон про споживчу кооперацію, 1992 (Верховна Рада України). Офіційний сайт Верховної Ради України <https://zakon.rada.gov.ua/laws/show/2265-12/conv\#Text> (2021, лютий, 12).

${ }^{10}$ Кучеренко, I. М. (2004). Організаційно-правові форми юридичних осіб приватного права. Київ: Інститут держави і права ім. В.М.Корецького НАН України, 28.

${ }^{11}$ Цивільний кодекс України, 2003 (Верховна Рада України). Офіиіийний сайт Верховної Ради України

<https://zakon.rada.gov.ua/laws/show/435-15\#Техt> (2021, лютий, 12).

12 Господарський кодекс України, 2003 (Верховна Рада України). Офіиійний сайт Верховної Ради Украйни

<https://zakon.rada.gov.ua/laws/show/436-15\#Text> (2021, лютий, 12).

13 Закон про державну реєстрацію юридичних осіб, фізичних осіб-підприємиів та громадських формувань, 2003 (Верховна Рада України). Голос України, 115, 24 черв.

14 Закон про холдингові компанії в Україні, 2006 (Верховна Рада України). Офіційний сайт Верховної Ради

України <https://zakon.rada.gov.ua/laws/show/3528-15\#Text> (2021, лютий, 12).

15 Закон про кооперацію, 2003 (Верховна Рада України). Офіційний сайт Верховної Ради України

<https://zakon.rada.gov.ua/laws/show/1087-15\#Text> (2021, лютий, 12).
} 
«Про сільськогосподарську кооперацію» ${ }^{1}$, Закон України «Про фермерське господарство» ${ }^{2}$, Закон України «Про акціонерні товариства» ${ }^{3}$, Закон України «Про товариства з обмеженою та додатковою відповідальністю» ${ }^{4}$, Указ Президента України «Про невідкладні заходи щодо прискорення реформування аграрного сектора економіки» ${ }^{5}$.

Однак така кількість нормативно-правових актів, які забезпечують регулювання статусу юридичних осіб, що вправі здійснювати виробничу діяльність у галузі сільського господарства з одного боку є позитивним явищем, адже забезпечує максимальну урегульованість відповідних відносин, а з іншого боку, - має деякі негативні наслідки, оскільки ці нормативно-правові акти подекуди містять взаємовиключні або суперечливі правила, що ускладнює правозастосування.

При цьому, безумовно, будь-які зміни правового регулювання статусу юридичних осіб повинні відбуватися як з врахуванням сучасних євроінтеграційних процесів, так i давніх традицій національної правової системи. Зокрема, варто погодитися з Ю. С. Шемшученком, що гармонізація систем національного та європейського права не може здійснюватися механічно (по-перше, продовжує діяти принцип державного суверенітету кожної країни; по-друге, ці країни мають багато особливостей, які не бережуть і не бажають розгубити у ході інтеграційних процесів; по-третє, досі не вироблено універсальних організаційних механізмів гармонізації відповідних правових систем; по-четверте, існують істотні недоліки у теоретичному вирішуванні відповідних проблем, що притримує їхнє практичне втілення). ${ }^{6}$

Прикладами неузгодженостей у правовому регулюванні статусу окремих видів сільськогосподарських юридичних осіб є, зокрема, кооперативи та фермерські господарства.

Зокрема, відповідно до ст. 2 Закону України «Про кооперацію» кооператив - це юридична особа, утворена фізичними та/або юридичними особами, які добровільно об'єдналися на основі членства для ведення спільної господарської та іншої діяльності з метою задоволення своїх економічних, соціальних та інших потреб на засадах самоврядування ${ }^{7}$.

Подібно, відповідно до ст. 1 Закону України «Про сільськогосподарську кооперацію» сільськогосподарський кооператив - це юридична особа, утворена фізичними та/або юридичними особами, які є виробниками сільськогосподарської продукції і добровільно об'єдналися на основі членства та на засадах самоврядування для провадження спільної господарської та іншої діяльності 3 метою задоволення економічних, соціальних та інших потреб 8

Відповідно до ч. 2 ст. 6 Закону України «Про споживчу кооперацію», колективними членами споживчого товариства можуть бути фермерські господарства, колективні сільськогосподарські підприємства, господарські товариства, кооперативні, державні та інші підприємства, що поділяють його цілі та інтереси'.

Також відповідно до ст. 163 ЦК України виробничим кооперативом є добровільне об'єднання громадян на засадах членства для спільної виробничої або іншої господарської діяльності, яка базується на їхній особистій трудовій участі та об'єднанні його членами майнових пайових внесків.

\footnotetext{
1 Закон про сільськогосподарську коопераџію, 2020 (Верховна Рада України). Офіиійний сайт Верховної Ради України <https://zakon.rada.gov.ua/laws/show/819-20\#Техt> (2021, лютий, 12).

2 Закон про фермерське господарство, 2003 (Верховна Рада України). Офіиійний сайт Верховної Ради Украӥни <https://zakon.rada.gov.ua/laws/show/973-15\#Техt> (2021, лютий, 12).

3 Закон про акціонерні товариства, 2008 (Верховна Рада України). Офіиійний сайт Верховної Ради Украӥни <https://zakon.rada.gov.ua/laws/show/514-17/conv\#Text> (2021, лютий, 12).

4 Закон про товариства з обмеженою та додатковою відповідальністю, 2018 (Верховна Рада України).

Офіиійний сайт Верховної Ради України <https://zakon.rada.gov.ua/laws/show/2275-19\#Text> (2021, лютий, 12).

${ }^{5}$ Указ про невідкладні заходи щуодо прискорення реформування аграрного сектора економіки, 1999 (Президент України). Офіиійний сайт Верховної Ради України <https://zakon.rada.gov.ua/laws/show/1529/99/conv\#Text> (2021, лютий, 12).

${ }^{6}$ Шемшученко, Ю. С. (2007). Теоретичні проблеми гармонізації законодавства України з європейським правом. Правова інформатика, 3 (15), 45.

7 Закон про кооперацію, 2003 (Верховна Рада України). Офіиійний сайт Верховної Ради України

<https://zakon.rada.gov.ua/laws/show/1087-15\#Техt> (2021, лютий, 12).

8 Закон про сільськогосподарську кооперацію, 2020 (Верховна Рада України). Офіиійний сайт Верховної Ради

України <https://zakon.rada.gov.ua/laws/show/819-20\#Text> (2021, лютий, 12).

9 Закон про споживчу коопераџію, 1992 (Верховна Рада України). Офіційний сайт Верховної Ради України <https://zakon.rada.gov.ua/laws/show/2265-12/conv\#Text> (2021, лютий, 12).
} 
Статутом кооперативу та законом може бути передбачено участь удіяльності виробничого кооперативу на засадах членства також інших осіб ${ }^{1}$.

Натомість згідно з ч. 1 ст. 94 ГК України кооперативи як добровільні об'єднання громадян 3 метою спільного вирішення ними економічних, соціально-побутових та інших питань можуть створюватися у різних галузях (виробничі, споживчі, житлові тощо) ${ }^{2}$.

B.I. Федорович подвійно визначає кооперацію як форму організації праці, за якої певна кількість осіб бере участь в одному й тому ж процесі праці, і як організаційно оформлені самодіяльні добровільні колективні об'єднання виробників, утворені для досягнення спільних цілейㄱ. Хоча більш вдалим видається підхід Б.М. Мартоса ${ }^{4}$ стосовно трактування кооперації як форми спільної діяльності на засадах співробітництва задля покращення добробуту, що розвинутий у працях М.А. Мацько та В.І.Семчика ${ }^{6}$.

Варто додати, що Закон України «Про сільськогосподарську кооперацію», який отримав правовий режим спеціального нормативного акту, призначеного належним чином врегулювати внутрішньогосподарські відносини в сільськогосподарських кооперативах з урахуванням особливостей та специфіки виробничого процесу в аграрній сфері економіки, насправді, не в повній мірі відповідає своєму призначенню. Його зміст не враховує наукових підходів вітчизняних науковців-правників, які протягом тривалого часу намагалися довести необхідність спеціалізованого правового регулювання членських, трудових, земельних, майнових, організаційних відносин у сільськогосподарських кооперативах, а також законодавчого закріплення специфічних прав та обов'язків членів сільськогосподарських кооперативів, обгрунтувати наявність особливостей правового механізму створення та припинення діяльності сільськогосподарських кооперативів, специфіки регулювання земельних відносин у сільськогосподарських кооперативах, а також необхідності прийняття окремих законів, що визначатимуть особливості правового статусу різних типів сільськогосподарських кооперативів ${ }^{7}$.

Таким чином, у юридичній літературі уже давно відзначають, що існуюча система нормативних актів, які визначають правове положення кооперативів, складається із неузгоджених між собою законодавчих актів, які суперечать один одному. Це якраз стосується Законів України «Про кооперацію», «Про споживчу кооперацію», «Про сільськогосподарську кооперацію» тощо .

Як правильно звертають увагу в наукових джерелах, на відміну від ЦК України, ГК України визначає право на членство у виробничих кооперативах тільки фізичних осіб. При цьому таку саму позицію має і Закон «Про кооперацію», визначаючи, що підставою для виключення з кооперативу $є$ припинення трудової участі в діяльності членів кооперативу. Зазначена концепція суперечить ЦК України, а отже, зазначені норми повинні бути виключені з ГК УКраїни та Закону «Про кооперацію» ${ }^{9}$. Також, як зазначає Н.І. Титова, у законі і в статутах усіх сільськогосподарських кооперативів має бути норма, відповідно до якої непрацездатні члени кооперативу зберігають свій правовий статус і користуються членськими правами ${ }^{10}$.

Іншим проблемним питанням регулювання статусу кооперативів, в тому числі сільськогосподарських, є питання підприємницької чи непідприємницької мети діяльності окремих їхніх видів. Так, у літературі обгрунтовували недоцільність розмежування виробничих та обслуговуючих кооперативів за раніше чинним законодавством шляхом віднесення перших

\footnotetext{
${ }^{1}$ Цивільний кодекс Украӥни, 2003 (Верховна Рада України). Офіиійний сайт Верховної Ради Украӥни <https://zakon.rada.gov.ua/laws/show/435-15\#Text> (2021, лютий, 12).

${ }^{2}$ Господарський кодекс України, 2003 (Верховна Рада України). Офіційний сайт Верховної Ради Украӥни <https://zakon.rada.gov.ua/laws/show/436-15\#Text> (2021, лютий, 12).

${ }^{3}$ Федорович, В. (1998). Правові основи створення та діяльності сільськогосподарських кооперативів в Україні. Львів: Атлас, 5.

${ }^{4}$ Мартос, Б. (1923). Теорія коопераиії. Подебради, 34.

${ }_{5}^{5}$ Семчик, В. І. (ред.) (1998). Предмет, система, витоки, суб'єкти кооперативного права. Київ: Ін Юре, 8.

${ }^{6}$ Семчик, В. И. (1991). Кооперация и право в СССР. Киев, 8.

${ }^{7}$ Тропін, В. В. (2016). Законодавство України про сільськогосподарську кооперацію: проблемні питання та шляхи їх вирішення. Вісник Дніпропетровського держсавного аграрно-економічного університету, 3 (41), 97-101, 98.

${ }^{8}$ Кучеренко, I. М. (2004). Організаційно-правові форми юридичних осіб приватного права. Київ: Інститут держави і права ім. В.М.Корецького НАН України, 29.

${ }^{9}$ Там само, 147.

${ }^{10}$ Титова, Н. І. (2000). Права членів сільськогосподарських кооперативів: тенденції та проблеми їх законодавчого забезпечення. Право України, 2, 26.
} 
до підприємницьких, a других - до непідприємницьких організацій та пропонували закріпити у ЦК України таку організаційно-правову форму як кооператив; навести узагальнююче поняття кооперативу, яке відповідає Декларації про кооперативну ідентичність, встановити суттєві ознаки такої форми і найзагальніші положення, які регламентують правовий статус кооперативу ${ }^{1}$. При цьому варто згадати про схвалену Кабінетом Міністрів України 03.03.2021 року постанову про модельні статути сільськогосподарських кооперативів. Зокрема, після набарання чинності Законом України «Про сісльськогосподарську кооперацію» від 2020 року поряд із скасуванням поділу таких кооперативів на виробничі та обслуговуючі закріплено підхід, відповідно до якого вони можуть створюватися як з метою, так і без мети одержання прибутку. Слідуючи такій логіці, можна зазначити про дискусійність підходу, адже виробничий кооператив відповідно до ЦК України і так залишається різновидом підприємницьких товариств, тобто таких юридичних осіб, які створюються і діють 3 метою одержання прибутку з наступним перерозподілом цього прибутку між членами кооперативу.

Не менш важливою $є$ також доцільність уніфікації підходів на рівні окремих законодавчих актів стосовно відповідальності членів кооперативів за його зобов'язаннями.

Наприклад, ЦК України передбачає субсидіарну відповідальність членів виробничого кооперативу за його зобов'язаннями у розмірах та порядку, окреслених законом і статутом (ч. 2 ст. 163), ГК України встановив субсидіарну (додаткову) відповідальність членів виробничого кооперативу їхнім майном у розмірі, не меншому від пайового внеску, якщо більший розмір відповідальності не визначений статутом чи законом (ч. 1 ст. 108), Закон України «Про кооперацію» закріпив відповідальність членів кооперативу за його зобов'язаннями у межах внесеного паю, якщо інше не передбачено законом чи статутом (ч. 2 ст. 27), Закон України «Про сільськогосподарську кооперацію» передбачив відповідальність члена кооперативу за його зобов'язаннями у межах частки, за винятком випадку, коли інше визначене законом (ч. 3 ст. 24), а Закон України «Про споживчу кооперацію»- відповідальність члена споживчого товариства обмежує винятково розміром пайового внеску (абз. 2 ч. 3 ст. 6).

Не менш цікавими у цьому контексті є фермерські господарства, які можуть створюватися як зі статусом юридичної особи, так і без такого статусу.

При цьому спірним вважалося питання трактування фермерських господарств як самостійних організаційно-правових форм юридичних осіб.

Зокрема, В.С. Щербина відмітив, що, на відміну від господарських товариств, фермерське господарство представлене лише головою, який, зокрема, вчиняє юридично-значущі дії від імені господарства відповідно до законодавства України ${ }^{2}$.

Натомість, I. М. Кучеренко зазначала, що ведення фермерського господарства пов'язане 3 певними пільгами, зокрема податковими, тому, незалежно від організаційно-правової форми ведення діяльності по виробленню сільськогосподарської продукції, фермерське господарство може існувати як у різних організаційно-правових формах господарських товариств, виробничих кооперативів, так і без створення юридичної особи ${ }^{3}$. Подібно, Ю.М. Юркевич, вказує, що фермерське господарство не $\epsilon$ самостійною організаційно-правовою формою юридичних осіб, а узагальнюючим поняттям, запровадженим з метою врегулювання особливостей ведення підприємницької діяльності у сфері сільського господарства та надання державної підтримки у цій галузі ${ }^{4}$.

У будь-якому випадку можливість ведення фермерської «за суттю» діяльності передбачена й іншими законодавчими актами. Так, наприклад, Законом України «Про особисте селянське господарство» встановлено, що особисте селянське господарство - це господарська діяльність, яка проводиться без створення юридичної особи фізичною особою індивідуально або особами, які перебувають у сімейних чи родинних відносинах і спільно проживають, з метою задоволення особистих потреб шляхом виробництва, переробки і споживання сільськогосподарської продукції, реалізації іiі

\footnotetext{
1 Чурилова, Т. М. (2011). Правове регулювання діяльності сільськогосподарських обслуговуючих кооперативів: дисертація на здобуття наукового ступеню кандидата юридичних наук. Київ: Інститут держави і права ім. В.М. Корецького НАН України, 8.

${ }^{2}$ Щербина, В. С. (2008). Суб'єкти господарського права. Київ: Юрінком Інтер, 76.

${ }^{3}$ Кучеренко, I. М. (2004). Організачійно-правові форми юридичних осіб приватного права. Київ Інститут держави і права ім. В.М.Корецького НАН України, 220.

${ }^{4}$ Юркевич, Ю. М. (2017). Договірні форми об’єднань фізичних та юридич- них осіб у цивільному праві України: дисертація на здобуття наукового ступеня доктора юридичних наук. Львів: Львівський державний університет внутрішніх справ, ЛНУ імені Івана Франка, 132.
} 
надлишків та надання послуг з використанням майна особистого селянського господарства, у тому числі й у сфері сільського зеленого туризму ${ }^{1}$. Іншим механізмом може виступити договір про спільну діяльність (простого товариства) у відповідності до Глави 77 ЦК України.

Висновки. Підсумовуючи вищеподане, вважаємо за доцільне зазначити, що юридичні особи, які провадять свою основну або додаткову підприємницьку чи некомерційну діяльність у галузі сільськогосподарського виробництва можуть бути поіменовані як сільськогосподарські юридичні особи. Поряд із тим до категорії цих суб' єктів не можна відносити юридичних осіб, які не займаються виробничою діяльністю в галузі сільського господарства, а посередницькою, торговельною чи іншою, наприклад здійснюють діяльність винятково із продажу сільськогосподарської продукції. Окрім цього, значна кількість нормативно-правових актів, які регламентують правовий статус сільськогосподарських юридичних осіб з одного боку є позитивним явищем, а з іншого боку - має деякі негативні наслідки, оскільки такі акти подекуди містять взаємовиключні або суперечливі правила, що ускладнює правозастосування. Відтак, зважаючи, зокрема, на проведену в Україні земельну реформу, актуальною є необхідність уніфікації підходів усфері регулювання статусу юридичних осіб, що провадять діяльність у галузі сільського господарства.

\section{References:}

1. Vinnyk, O. M. (1998). Hospodarski tovarystva i vyrobnychi kooperatyvy: pravove stanovyshche [Business associations and production cooperatives: legal status]. Kyiv: Znannya. [in Ukrainian].

2. Vinnyk, O. M. (2009). Hospodarske pravo [Commercial law]. Kyiv: Legal unity. [in Ukrainian].

3. The Food and Agriculture Organization of the UN (2009) Deklaratsiya Vsemirnogo sammita po prodovolstvennoy bezopasnosti (Rim, 16-18 noyabrya) [Declaration of the World Summit on Food Security (Rome, November 16-18)]. <http://www.fao.org/fileadmin/templates/wsfs/Summit/Docs/Final_Declaration/K6050_Rev10_WSFS_OEWG_ru.pdf> (2020, November, 10). [in Russian].

4. Hospodarskyy kodeks Ukrayiny, 2003 (Verkhovna Rada Ukrayiny) [Economic Code of Ukraine, 2003 (Verkhovna Rada of Ukraine)]. Ofitsiynyy sayt Verkhovnoyi Rady Ukrayiny [Official site of the Verkhovna Rada of Ukraine] <https://zakon.rada.gov.ua/laws/show/436-15\#Text> (2021, February, 12). [in Ukrainian].

5. Zakon pro aktsionerni tovarystva, 2008 (Verkhovna Rada Ukrayiny) [Law on Joint Stock Companies, 2008 (Verkhovna Rada of Ukraine)]. Ofitsiynyy sayt Verkhovnoyi Rady Ukrayiny [Official site of the Verkhovna Rada of Ukraine] <https://zakon.rada.gov.ua/laws/show/514-17/conv\#Text> (2021, February, 12). [in Ukrainian].

6. Zakon pro hospodarski tovarystva, 1991 (Verkhovna Rada Ukrayiny) [Law on Business Associations, 1991 (Verkhovna Rada of Ukraine)]. Ofitsiynyy sayt Verkhovnoyi Rady Ukrayiny [Official site of the Verkhovna Rada of Ukraine] <https://zakon.rada.gov.ua/laws/show/1576-12\#Text> (2021, February, 12). [in Ukrainian].

7. Zakon pro derzhavnu reyestratsiyu yurydychnykh osib, fizychnykh osib-pidpryyemtsiv ta hromadskykh formuvan, 2003 (Verkhovna Rada Ukrayiny) [Law on State Registration of Legal Entities, Individual Entrepreneurs and Public Associations, 2003 (Verkhovna Rada of Ukraine)]. Holos Ukrayiny [Voice of Ukraine], 115, 24 June. [in Ukrainian].

8. Zakon pro kolektyvne silskohospodarske pidpryyemstvo, 1992 (Verkhovna Rada Ukrayiny) [Law on Collective Agricultural Enterprise, 1992 (Verkhovna Rada of Ukraine)]. Ofitsiynyy sayt Verkhovnoyi Rady Ukrayiny [Official site of the Verkhovna Rada of Ukraine] <https://zakon.rada.gov.ua/laws/show/2114-12\#Text> (2021, February, 12). [in Ukrainian].

9. Zakon pro kolektyvne silskohospodarske pidpryyemstvo, 1992 (Verkhovna Rada Ukrayiny) [Law on Collective Agricultural Enterprise, 1992 (Verkhovna Rada of Ukraine)]. Ofitsiynyy sayt Verkhovnoyi Rady Ukrayiny [Official site of the Verkhovna Rada of Ukraine] <https://zakon.rada.gov.ua/laws/show/1087-15\#Text> (2021, February, 12). [in Ukrainian].

10. Zakon pro osobyste selyanske hospodarstvo, 2003 (Verkhovna Rada Ukrayiny) [Law on Personal Peasant Economy, 2003 (Verkhovna Rada of Ukraine)]. Ofitsiynyy sayt Verkhovnoyi Rady Ukrayiny [Official site of the Verkhovna Rada of Ukraine] <https://zakon.rada.gov.ua/laws/show/742-15\#Text> (2021, February, 12). [in Ukrainian].

11. Zakon pro pidpryyemnytstvo, 1991 (vtratyv chynnist, okrim st. 4). (Verkhovna Rada Ukrayiny) [Law on Entrepreneurship, 1991 (repealed, except for Article 4). (Verkhovna Rada of Ukraine)]. Ofitsiynyy sayt Verkhovnoyi Rady Ukrayiny [Official site of the Verkhovna Rada of Ukraine] $<$ https://zakon.rada.gov.ua/laws/show/698-12\#Text> (2021, February, 12). [in Ukrainian].

12. Zakon pro pidpryyemstva v Ukrayini, 1991 (vtratyv chynnist) (Verkhovna Rada Ukrayiny) [Law on Enterprises in Ukraine, 1991 (repealed) (Verkhovna Rada of Ukraine)]. Ofitsiynyy sayt Verkhovnoyi Rady Ukrayiny [Official site of the Verkhovna Rada of Ukraine] <https://zakon.rada.gov.ua/laws/show/887-12\#Text> (2021, February, 12). [in Ukrainian].

\footnotetext{
1 Закон про особисте селянське господарство, 2003 (Верховна Рада України). Офіційний сайт Верховної Ради Украӥни <https://zakon.rada.gov.ua/laws/show/742-15\#Text> (2021, лютий, 12).
} 
13. Zakon pro promyslovo-finansovi hrupy v Ukrayini, 1995 (vtratyv chynnist). (Verkhovna Rada Ukrayiny). Ofitsiynyy sayt Verkhovnoyi Rady Ukrayiny [Official site of the Verkhovna Rada of Ukraine] <https://zakon.rada.gov.ua/laws/show/437/95-\%D0\%B2\%D1\%80\#Text> (2021, February, 12). [in Ukrainian].

14. Zakon pro selyanske (fermerske) hospodarstvo, 1991 (vtratyv chynnist) (Verkhovna Rada Ukrayiny) [Law on Peasant (Farming) Economy, 1991 (repealed) (Verkhovna Rada of Ukraine)]. Ofitsiynyy sayt Verkhovnoyi Rady Ukrayiny [Official site of the Verkhovna Rada of Ukraine] 〈https://zakon.rada.gov.ua/laws/show/2009-12\#Text> (2021, February, 12). [in Ukrainian].

15. Zakon pro silskohospodarsku kooperatsiyu, 2020 (Verkhovna Rada Ukrayiny) [Law on Agricultural Cooperation, 2020 (Verkhovna Rada of Ukraine)]. Ofitsiynyy sayt Verkhovnoyi Rady Ukrayiny [Official site of the Verkhovna Rada of Ukraine] <https://zakon.rada.gov.ua/laws/show/819-20\#Text> (2021, February, 12). [in Ukrainian].

16. Zakon pro spozhyvchu kooperatsiyu, 1992 (Verkhovna Rada Ukrayiny) [Law on Consumer Cooperation, 1992 (Verkhovna Rada of Ukraine)]. Ofitsiynyy sayt Verkhovnoyi Rady Ukrayiny [Official site of the Verkhovna Rada of Ukraine] <https://zakon.rada.gov.ua/laws/show/2265-12/conv\#Text> (2021, February, 12). [in Ukrainian].

17. Zakon pro tovarystva z obmezhenoyu ta dodatkovoyu vidpovidalnistyu, 2018 (Verkhovna Rada Ukrayiny) [Law on Limited and Additional Liability Companies, 2018 (Verkhovna Rada of Ukraine)]. Ofitsiynyy sayt Verkhovnoyi Rady Ukrayiny [Official site of the Verkhovna Rada of Ukraine] 〈https://zakon.rada.gov.ua/laws/show/2275-19\#Text> (2021, February, 12). [in Ukrainian].

18. Zakon pro fermerske hospodarstvo, 2003 (Verkhovna Rada Ukrayiny) [Law on Farming, 2003 (Verkhovna Rada of Ukraine)]. Ofitsiynyy sayt Verkhovnoyi Rady Ukrayiny [Official site of the Verkhovna Rada of Ukraine] <https://zakon.rada.gov.ua/laws/show/973-15\#Text> (2021, February, 12). [in Ukrainian].

19. Zakon pro kholdynhovi kompaniyi v Ukrayini, 2006 (Verkhovna Rada Ukrayiny) [Law on Holding Companies in Ukraine, 2006 (Verkhovna Rada of Ukraine)]. Ofitsiynyy sayt Verkhovnoyi Rady Ukrayiny [Official site of the Verkhovna Rada of Ukraine] <https://zakon.rada.gov.ua/laws/show/3528-15\#Text> (2021, February, 12). [in Ukrainian].

20. Klyukin, B. D. (1972). Pravovoye regulirovaniye selskogo khozyaystva v SSHA [Legal regulation of agriculture in the United States]: avtoreferat dissertatsii na soiskaniye nauchnoy stepeni doktora yuridicheskikh nauk [thesis abstract for the degree of Doctor of Laws]. Moscow: USSR Academy of Sciences. Institute of State and Law.

21. Kossak, V. M. (1990). Sovershenstvovaniye pravovogo regulirovaniya yuridicheskoy otvetstvennosti kooperativnykh organizatsiy [Improving the legal regulation of the legal responsibility of cooperative organizations]. Problemy prava kooperativnoy sobstvennosti i yuridicheskoy otvetstvennosti uchastnikov kooperativnogo dvizheniya v pravoprimenitelnoy i pravotvorcheskoy deyatelnosti [Problems of the law of cooperative property and legal responsibility of participants in the cooperative movement in law enforcement and lawmaking activities]. Kharkov. [in Russian].

22. Kuznetsova, N. S. (2012). Ponyattya y klasyfikatsiya yurydychnykh osib v tsyvilnomu pravi Ukrayiny: teoriya i praktyka [The concept and classification of legal entities in the civil law of Ukraine: theory and practice]. Suchasni problemy pryvatnoho prava: zbirnyk naukovykh prats prysvyachenykh 80-iy richnytsi z Dnya narodzhennya Yaroslavny Mykolayivny Shevchenko [Modern problems of private law: a collection of scientific papers dedicated to the 80th anniversary of the birth of Yaroslavna Shevchenko]. Kyiv: Asotsiatsiya tsyvilistiv Ukrayiny, Kamyanets-Podilskyy: Ruta. [in Ukrainian].

23. Kucherenko, I. M. (2004). Orhanizatsiyno-pravovi formy yurydychnykh osib pryvatnoho prava [Organizational and legal forms of legal entities of private law]: dysertatsiya na zdobuttya naukovoho stupenya doktora yurydychnykh nauk [dissertation for the degree of Doctor of Laws]. Kyiv: Instytut derzhavy i prava im. V.M.Koretskoho NAN Ukrayiny. [in Ukrainian].

24. Kucherenko, I. M. (2004). Orhanizatsiyno-pravovi formy yurydychnykh osib pryvatnoho prava [Organizational and legal forms of legal entities of private law]. Kyiv: Instytut derzhavy i prava im. V.M.Koretskoho NAN Ukrayiny. [in Ukrainian].

25. Martos, B. (1923). Teoriya kooperatsiyi [Theory of cooperation]. Podyebrady. [in Russian].

26. Semchik, V. I. (1991). Kooperatsiya i pravo v SSSR [Cooperation and law in the USSR]. Kiev. [in Russian].

27. Semchyk, V. I. (ed.) (1998). Predmet, systema, vytoky, subyekty kooperatyvnoho prava [Subject, system, origins, subjects of cooperative law]. Kyiv: In Yure. [in Ukrainian].

28. Spasybo-Fatyeyeva, I. V. (2014). Vchennya pro korporatyvni prava i tsyvilistychna doktryna [The doctrine of corporate rights and civil doctrine]. Pravo Ukrayiny [Law of Ukraine], 6, 84-92. <http://dspace.nlu.edu.ua/bitstream/123456789/6144/1/Spasybo-Fatieieva_84_92.pdf> (2021, March, 02). [in Ukrainian].

29. Tytova, H. I. (2000). Prava chleniv silskohospodarskykh kooperatyviv: tendentsiyi ta problemy yikh zakonodavchoho zabezpechennya [Rights of members of agricultural cooperatives: trends and problems of their legislative support]. Pravo Ukrayiny [Law of Ukraine], 2, 26. [in Ukrainian].

30. Tropin, V. V. (2016). Zakonodavstvo Ukrayiny pro silskohospodarsku kooperatsiyu: problemni pytannya ta shlyakhy yikh vyrishennya [Legislation of Ukraine on agricultural cooperation: problematic issues and ways to solve them]. Visnyk Dnipropetrovskoho derzhavnoho ahrarno-ekonomichnoho universytetu [Bulletin of Dnipropetrovsk State Agrarian and Economic University], 3 (41), 97-101. [in Ukrainian]. 
31. Ukaz pro nevidkladni zakhody shchodo pryskorennya reformuvannya ahrarnoho sektora ekonomiky, 1999 (Prezydent Ukrayiny) [Decree on urgent measures to accelerate the reform of the agricultural sector of the economy, 1999 (President of Ukraine)]. Ofitsiynyy sayt Verkhovnoyi Rady Ukrayiny [Official site of the Verkhovna Rada of Ukraine] <https://zakon.rada.gov.ua/laws/show/1529/99/conv\#Text> (2021, February, 12). [in Ukrainian].

32. Fedorovych, V. (1998). Pravovi osnovy stvorennya ta diyalnosti silskohospodarskykh kooperatyviv v Ukrayini [Legal bases of creation and activity of agricultural cooperatives in Ukraine]. Lviv: Atlas. [in Ukrainian].

33. Tsyvilnyy kodeks Ukrayiny, 2003 (Verkhovna Rada Ukrayiny). Ofitsiynyy sayt Verkhovnoyi Rady Ukrayiny [Official site of the Verkhovna Rada of Ukraine] 〈https://zakon.rada.gov.ua/laws/show/435-15\#Text> (2021, February, 12). [in Ukrainian].

34. Tsyvilnyy kodeks Ukrayinskoyi RSR, 1963 (vtratyv chynnist) (Verkhovna Rada URSR) [Civil Code of the Ukrainian SSR, 1963 (repealed) (Verkhovna Rada of the USSR)]. Ofitsiynyy sayt Verkhovnoyi Rady Ukrayiny [Official site of the Verkhovna Rada of Ukraine] <https://zakon.rada.gov.ua/laws/show/1540-06\#Text> (2021, February, 12). [in Ukrainian].

35. Tsikalo, V. I. (2008). Osnovy pravovoho rehulyuvannya pidpryyemnytskoyi diyalnosti [Fundamentals of legal regulation of entrepreneurial activity]. In: Ortynskyy, V. L., Hryshchuk, V. K., Matsko, M. A. (ed.) (2008). Osnovy derzhavy i prava Ukrayiny [Fundamentals of the state and law of Ukraine]. Kyiv: Znannya, $I V$. [in Ukrainian].

36. Churylova, T. M. (2011). Pravove rehulyuvannya diyalnosti silskohospodarskykh obsluhovuyuchykh kooperatyviv [Legal regulation of agricultural service cooperatives]: dysertatsiya na zdobuttya naukovoho stupenyu kandydata yurydychnykh nauk [dissertation for the degree of Candidate of Law]. Kyiv: Instytut derzhavy i prava im. V.M. Koretskoho NAN Ukrayiny. [in Ukrainian].

37. Shemshuchenko, Yu. S. (2007). Teoretychni problemy harmonizatsiyi zakonodavstva Ukrayiny z yevropeyskym pravom [Theoretical problems of harmonization of Ukrainian legislation with European law]. Pravova informatyka [Legal informatics], 3 (15), 45. [in Ukrainian].

38. Shcherbyna, V. S. (2008). Subyekty hospodarskoho prava [Business entities]. Kyiv: Yurinkom Inter. [in Ukrainian].

39. Yurkevych, Yu. M. (2016). Fermerske hospodarstvo yak obyednannya fizychnykh osib z metoyu realizatsiyi pidpryyemnytskykh interesiv u sferi zdiysnennya profesiynoyi diyalnosti [Farm as an association of individuals in order to realize business interests in the field of professional activity]. Aktualni problemy derzhavy i prava [Current issues of state and law], 77, 209-214. [in Ukrainian].

40. Yurkevych, Yu. M. (2017). Dohovirni formy obyednan fizychnykh ta yurydychnykh osib u tsyvilnomu pravi Ukrayiny [Contractual forms of associations of individuals and legal entities in the civil law of Ukraine]: dysertatsiya na zdobuttya naukovoho stupenya doktora yurydychnykh nauk [dissertation for the degree of Doctor of Laws]. Lviv: Lvivskyy derzhavnyy universytet vnutrishnikh sprav, LNU imeni Ivana Franka. [in Ukrainian].

41. Yurkevych, Yu. M. (ed.) (2019). Pravovi zasady stvorennya, diyalnosti ta prypynennya yurydychnykh osib $v$ Ukrayini [Legal bases of creation, activity and termination of legal entities in Ukraine]. Lviv: Lviv Department of Internal Affairs. [in Ukrainian]. 